\title{
Clostridium Difficile and Fecal Microbial Transplant in Critically III
} Patients

Sarvin Sanaie ${ }^{1^{*}}$

1.Faculty of Nutrition, Tabriz University of Medical Sciences

Critically-ill patients constitute majority of the patients hospitalized in ICU wards $(1,2)$. This group of patients demands special considerations and measures of care (3-6). Clostridium difficile infection causes dangerous, painful and persistent diarrhea in critically ill patients. Its treatment consists of enteral metronidazol or vancomycin in combination with IV antibiotics cessation. Recently, probiotics have been considered as an alternative treatment for pseudomembranous colitis. In 1958, fecal microbial transplant was first described from healthy individuals to sick patients to displace pathogenic microbes from the intestine by re-establishing a healthy microbial community. Since then, it has gained value as "express stool treatment" or currently known as "fecal transplant". Last year, FDA classified stool as drug, which typically requires an Investigational New Drug application (IND). However, in July 2013, the FDA issued guidance stating that it would exercise enforcement discretion for physicians administering FMT to treat patients with recurrent Clostridium difficile infection. Accordingly, considering stool as a tissue product or giving it its own classification, as FDA approved for blood, would keep patients safe, ensure broad access and facilitate research (7).

It should be taken into consideration that some complications might accompany fecal microbial transplant such as making patients susceptible for conditions like obesity or autoimmune disorders.

Safety and quality assurance starts from preenrollment donor screening, donor testing (17 serological and stool-based assays), donor monitoring and process control. The composition of the bacterial community has been shown to change when stored at $-800 \mathrm{C}$ compared to the samples stored at $-200 \mathrm{C}$ and it has been recommended to store the samples of intestinal content at $-20 \mathrm{oC}$ before use for bacterial community analysis, instead of the current practice at $-80 \circ \mathrm{C}(7,8)$. However, if samples have to be thawed repeatedly, addition of glycerol is preferable and showed that after 1 year storage at $-70 \circ \mathrm{C}$ is preferable to $-200 C$ considering microbial count (9). At the end it seems that for long duration storage at -

Corresponding author:

Sarvin Sanaie.MD.

Faculty of Nutrition, Tabriz University of Medical Sciences

Receive date: 2014-02-15 | Accept date: 2014-03-18 | Publish date:

2014-03-22 DOI: 10.7575/aiac.abcmed.14.02.02.03 
$80 \circ \mathrm{C}$ is sufficient and for short duration $-200 \mathrm{C}$ is preferable. Although, it is necessary to pick several isolates per sample in order to obtain at least one isolate representing the dominating strains. Finally, fecal specimens could be combined with prebiotics in order to achieve their optimal efficacy. Hence, future prospective clinical trials are required to detect and approve the efficacy and safety of fecal transplants in critical ill patients.

\section{Conflict of interest statement}

The author have no conflict of interest to declare.

\section{References}

1. Hasanloei MA, Mahoori A, Bazzazi AM, Golzari SE, Karami T. Percutaneous Dilatational Tracheostomy and Surgically Created Tracheostomy in ICU Patients. J Cardiovasc Thorac Res, 2014, 6(1), 43-46. doi: 10.5681/jcvtr.2014.008

2. Mahmoodpoor A, Golzari SE. APRV Mode in Ventilator Induced Lung Injury (VILI). ABC med. doi:10.7575/aiac.abcmed.v.2n.1p.1

3. Sanaie S, Mameghani ME, Mahmoodpoor A, Shadvar K, Golzari SE. Effect of a Probiotic Preparation (VSL\#3) on Cardiovascular Risk Parameters in Critically-III Patients. Journal of Cardiovascular and Thoracic Research. 2013;5(2);6770

4. Golzari SE, Mahmoodpoor A. Decatecholaminization and Calcium Sensitizers in Critically III Patients. Res Cardiovasc Med. 2014;2(1):e16714.

5. Mahmoodpoor A, Golzari SE, Kermani TA, Hasankandi HS, Soleimanpour H. Universal Glove and Gown Use for Healthcare Workers: What Is the Role of Visitors? J Cardiovasc Thorac Res, 2013, 5(4), 173

6. Mahmoodpoor A, Golzari SE, Sanaie S. Early enteral nutrition and optimization of the energy with supplemental parenteral nutrition. Int J Surg. 2014. doi: 10.1016/j.ijsu.2014.02.005.

7. Kelly C, Alm E.J. How to regulate fecal transplant? Nature 2014; 506: 290-291.

8. Mølbak L, Sommer HM, Johnsen K, Boye M, Johansen M, Møller K, Leser TD. Freezing at -800 degrees C distorts the DNA composition of bacterial communities in intestinal samples. Curr Issues Intest Microbiol 2006; 7(1):29-34.

9. Achá SJ, Kühn I, Mbazima G, Colque-Navarro P, Möllby R. Changes of viability and composition of the Escherichia coli flora in faecal samples during long time storage. J Microbiol Methods. 2005 Dec; 63(3):229-38. 